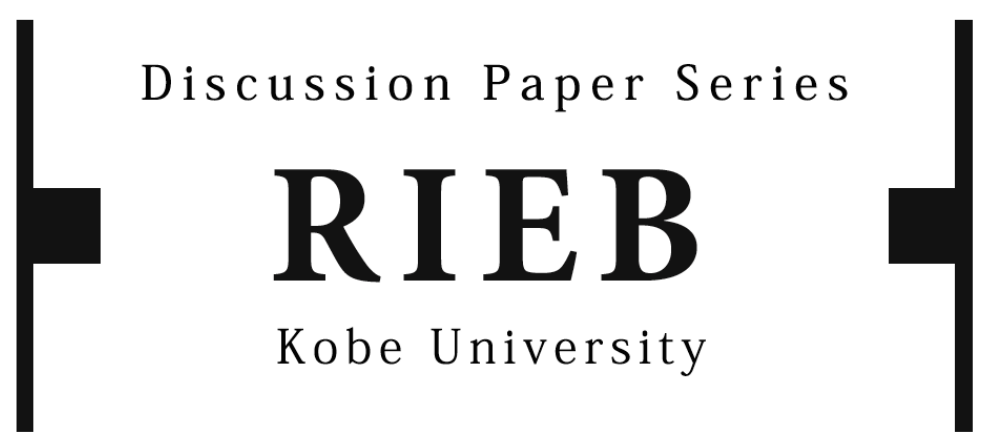

DP2013-36

\title{
External Debt and Taylor Rules in a Small Open Economy
}

\author{
Shigeto KITANO \\ Kenya TAKAKU
}

Revised January 13, 2016

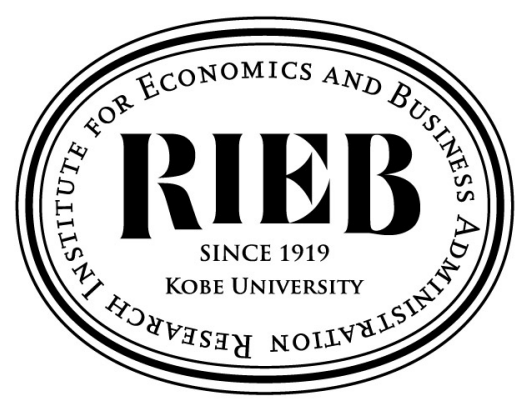

Research Institute for Economics and Business Administration Kobe University 


\title{
External debt and Taylor rules in a small open economy*
}

\author{
Shigeto Kitano ${ }^{\dagger} \quad$ Kenya Takaku ${ }^{\ddagger}$
}

\begin{abstract}
We develop a dynamic stochastic general equilibrium model of a small open economy in which both price rigidity and financial friction exist. We compare two cases featuring different interest rate rules. Both cases use the standard Taylor-type interest rate rules, but the second case also considers external debt levels. We find that when friction in foreign borrowing is large, adding an external debt level to Taylor rules improves welfare. The welfare curve, however, exhibits a hump shape since excessive reactions to changes in external debt reduce welfare.
\end{abstract}

Keywords: External debt; Taylor rules; small open economy; DSGE; welfare; emerging market economies.

JEL Classification: E5, F4.

*Earlier versions of the paper were presented at the tenth annual conference, AsiaPacific Economic Association in Bangkok, the Japan Society of Monetary Economics, and Kobe University. The authors thank the seminar participants for helpful comments. The authors are especially grateful to two anonymous referees, Takashi Kamihigashi, Ryo Kato, Masahiko Shibamoto, Eiji Okano, and Chikafumi Nakamura for valuable comments. Any remaining errors are ours. This work was supported by Grants-in-Aid for Scientific Research.

${ }^{\dagger}$ RIEB, Kobe University, 2-1, Rokkodai, Nada, Kobe, 657-8501 Japan, E-mail: kitano@rieb.kobe-u.ac.jp.

${ }^{\ddagger}$ Faculty of Business, Aichi Shukutoku University, 23, Sakuragaoka, Chikusa, Nagoya, 464-8671, Japan, E-mail: ktakaku@asu.aasa.ac.jp. 


\section{Introduction}

Taylor rules are simple monetary policy rules that govern how a central bank should systematically adjust the nominal interest rate in response to changes in inflation and other macroeconomic variables. Since Taylor (1993), a large body of literature has shown that these rules provide a reasonable empirical description of the policy behavior exhibited by many central banks (e.g., Clarida et al. (1998)).

In addition, further studies have examined whether welfare can be improved if other macro-variables such as foreign exchange rates and asset prices are added to the standard Taylor rules. Taylor (2001) surveyed literature examining the policy effect when exchange rates are added to Taylor rules (e.g., Ball (1999) and Svensson (2000)). Taylor (2001) concluded that the economic improvement would be small or might even decline if exchange rates were added when controlling inflation rate and output gap volatility. Senay (2008) performed a welfare analysis based on a small open dynamic stochastic general equilibrium (DSGE) model with price rigidity and micro-foundations. The results suggested that including exchange rates would reduce welfare. ${ }^{1}$ Bernanke and Gertler (1999) incorporated a bubble crisis into the financial accelerator model of Bernanke et al. (1999) and examined whether to add asset prices to Taylor-type interest rate rules. They concluded that monetary authorities should not consider asset prices in their monetary policy. However, Cecchetti et al. (2000) considered a generalized version of the model

\footnotetext{
${ }^{1}$ The theoretical models in the literature presented by Taylor (2001) lacked microfoundations. Whereas Svensson (2000) developed a model based on micro-foundations, the welfare loss function is set in an ad hoc way.
} 
used by Bernanke and Gertler (1999) and advised that interest rates respond to stock prices.

The recent financial crisis has revived the long-standing debate concerning whether monetary authorities should consider variables other than inflation and output gaps. More recent studies have suggested that the central bank may improve welfare by including such additional variables in monetary policy rules. Studies such as those by Christiano et al. (2007), Christiano et al. (2008), Cúrdia and Woodford (2010), Gray et al. (2011), and Kannan et al. (2012) have shown that gains can result from including additional variables such as credit growth, credit spreads, or financial stability indicators.

This paper focuses on emerging market economies. Business cycles in such economies are amplified by recurrent capital flow booms and busts. Increasing interest in this phenomenon has resulted in a fast-growing body of literature investigating prudential policies concerning capital inflows (e.g., Jeanne and Korinek (2010); Korinek (2011); Jeanne et al. (2012)). ${ }^{2}$ Building on this background, we developed a model that includes external debt in the standard Taylor rules. We considered whether it is welfare improving to use monetary policy to increase interest rates when capital inflows are booming and external debt is accumulating. To examine if including external debt in the standard Taylor rules may improve an economy's welfare, we developed a standard DSGE model of a small open economy calibrated to reflect emerging market economies, incorporating both price rigidity and a reduced form of financial friction à la Garcia-Cicco et al. (2010).

\footnotetext{
${ }^{2}$ For details on the new literature on capital controls, see Korinek (2011) or Jeanne et al. (2012). For the earlier literature, see the introduction in Kitano (2011).
} 
Our argument is closely related to the argument made by Garcia-Cicco et al. (2010) on a country-specific interest-rate premium. Garcia-Cicco et al. (2010) showed that the country-specific interest-rate premium parameter can play an important role in replicating the business cycle seen in emerging market economies. Moreover, they argued that "the role of the debt elasticity of the country premium is no longer limited to simply inducing stationarity, but to potentially act as the reduced form of a financial friction shaping the model's response to aggregate disturbances." The country premiums of emerging market economies are significantly higher than those of developed countries. In addition, the country premium rises as a country accumulates external debt. Our analysis showed that as the debt elasticity of the country premium rises, it becomes increasingly important for policy makers in emerging market economies to incorporate external debt levels into their monetary policy decisions.

The remainder of the paper is organized as follows. In Section 2, we present a DSGE model of a small open economy including both price rigidity and financial friction. In Section 3, we calibrate our model to match key characteristics of emerging economies. In Section 4, we perform a comparative analysis of welfare in two interest rate rule scenarios. Both cases use the standard Taylor-type interest rate rules, but the second case also considers external debt levels. Conclusions are presented in Section 5. 


\section{The Model}

We employ a simple small open sticky price DSGE model. ${ }^{3}$ The model's world economy consists of two separate economies, a small open economy (home country) and the rest of the world's economy (foreign country). Each economy includes a continuum of infinitely-lived agents (households and firms).

Households have access to domestic and foreign asset markets. We assume that households face a country-specific interest rate premium in their foreign borrowing. Firms produce differentiated goods by using capital and labor in a monopolistic competitive market.

\subsection{Households}

A representative household will seek to maximize

$$
E_{0} \sum_{t=0}^{\infty} \beta^{t} \frac{\left(C_{t}-\chi N_{t}^{\phi}\right)^{1-\sigma}-1}{1-\sigma}, \chi>0, \phi>1, \sigma>0
$$

where $E_{t}$ denotes the mathematical expectations operator conditional on information available at time $t, \beta \in(0,1)$ is the discount factor, $C_{t}$ signifies a composite consumption index, and $N_{t}$ represents labor effort. The intertemporal elasticity of substitution is given by $\frac{1}{\sigma}$, and the elasticity of labor supply is given by $\frac{1}{\phi-1}$. Households consume differentiated goods (produced by both domestic and foreign firms). The composite consumption index $C_{t}$ is given

\footnotetext{
${ }^{3}$ The model here is based on the small open economy structure developed by Galí and Monacelli (2005) and Faia and Monacelli (2008).
} 
by

$$
C_{t} \equiv\left[(1-\gamma)^{\frac{1}{\eta}} C_{H, t}^{\frac{\eta-1}{\eta}}+\gamma^{\frac{1}{\eta}} C_{F, t}^{\frac{\eta-1}{\eta}}\right]^{\frac{\eta}{\eta-1}}
$$

The parameter $\eta(>0)$ is the elasticity of substitution between domestic and foreign goods, and the parameter $\gamma \in(0,1)$ represents the measure of openness. $C_{H, t}$ and $C_{F, t}$ are the indices of consumption of domestic and foreign goods, expressed by

$$
C_{H, t} \equiv\left[\int_{0}^{1} C_{H, t}(j)^{\frac{\varepsilon-1}{\varepsilon}} d j\right]^{\frac{\varepsilon}{\varepsilon-1}} ; \quad C_{F, t} \equiv\left[\int_{0}^{1} C_{F, t}(j)^{\frac{\varepsilon-1}{\varepsilon}} d j\right]^{\frac{\varepsilon}{\varepsilon-1}}
$$

where $\varepsilon(>1)$ is the parameter for the elasticity of substitution among differentiated goods. A household's optimal expenditure allocation in each goods category yields the demand functions for domestic and foreign differentiated goods: ${ }^{4}$

$$
C_{H, t}(j)=\left(\frac{P_{H, t}(j)}{P_{H, t}}\right)^{-\varepsilon} C_{H, t} ; \quad C_{F, t}(j)=\left(\frac{P_{F, t}(j)}{P_{F, t}}\right)^{-\varepsilon} C_{F, t}
$$

where $P_{H, t}(j)$ and $P_{F, t}(j)$ denote the domestic-currency-denominated prices of differentiated goods $j$ produced by domestic and foreign firms, respectively. $P_{H, t}$ and $P_{F, t}$ are the domestic and import price index, respectively:

$$
P_{H, t} \equiv\left[\int_{0}^{1} P_{H, t}(j)^{1-\varepsilon} d j\right]^{\frac{1}{1-\varepsilon}} ; \quad P_{F, t} \equiv\left[\int_{0}^{1} P_{F, t}(j)^{1-\varepsilon} d j\right]^{\frac{1}{1-\varepsilon}} .
$$

\footnotetext{
${ }^{4}$ More specifically, the optimal expenditure allocation is given by minimizing $\int_{0}^{1} P_{i, t}(j) C_{i, t}(j) d j$, subject to $C_{i, t} \equiv\left[\int_{0}^{1} C_{i, t}(j)^{\frac{\varepsilon-1}{\varepsilon}} d j\right]^{\frac{\varepsilon}{\varepsilon-1}}$ for $i=H$ or $F$.
} 
From Eq. (5), it follows that

$$
\int_{0}^{1} P_{H, t}(j) C_{H, t}(j) d j=P_{H, t} C_{H, t} ; \quad \int_{0}^{1} P_{F, t}(j) C_{F, t}(j) d j=P_{F, t} C_{F, t} .
$$

The optimal expenditure allocation between domestic and imported goods gives

$$
C_{H, t}=(1-\gamma)\left(\frac{P_{H, t}}{P_{t}}\right)^{-\eta} C_{t} ; \quad C_{F, t}=\gamma\left(\frac{P_{F, t}}{P_{t}}\right)^{-\eta} C_{t}
$$

where $P_{t}$ represents the consumer price index $(\mathrm{CPI})$ :

$$
P_{t} \equiv\left[(1-\gamma) P_{H, t}^{1-\eta}+\gamma P_{F, t}^{1-\eta}\right]^{\frac{1}{1-\eta}}
$$

From Eqs. (7) and (8), we obtain

$$
P_{H, t} C_{H, t}+P_{F, t} C_{F, t}=P_{t} C_{t}
$$

A household's budget constraint in period $t$ is given as

$P_{t} C_{t}+P_{t} I_{t}+T_{t}+\left(1+i_{t-1}\right) A_{t-1}+\left(1+i_{t-1}^{f}\right) \mathcal{E}_{t} B_{t-1}=A_{t}+\mathcal{E}_{t} B_{t}+W_{t} N_{t}+R_{t} K_{t}+\Pi_{t}^{F}$,

where $I_{t}$ is aggregate investment, $T_{t}$ is lump-sum tax, $i_{t}$ is the interest rate at which households can borrow in the domestic asset market (i.e., the nominal interest rate), $A_{t}$ is the domestic debt position, $i_{t}^{f}$ is the interest rate at which households can borrow in the foreign asset market, $\mathcal{E}_{t}$ represents the nominal exchange rate (in terms of the domestic currency), $B_{t}$ is the country's foreign debt position, $W_{t}$ is the nominal wage, $R_{t}$ is the rental rate of capital, $K_{t}$ 
stands for capital, and $\Pi_{t}^{F}$ denotes dividends from firms. $I_{t}$ is composed of domestic and imported goods:

$$
I_{t} \equiv\left[(1-\gamma)^{\frac{1}{\eta}} I_{H, t}^{\frac{\eta-1}{\eta}}+\gamma^{\frac{1}{\eta}} I_{F, t}^{\frac{\eta-1}{\eta}}\right]^{\frac{\eta}{\eta-1}}
$$

$I_{H, t}$ and $I_{F, t}$ are the indices of investment of domestic and foreign goods, represented by

$$
I_{H, t} \equiv\left[\int_{0}^{1} I_{H, t}(j)^{\frac{\varepsilon-1}{\varepsilon}} d j\right]^{\frac{\varepsilon}{\varepsilon-1}} ; \quad I_{F, t} \equiv\left[\int_{0}^{1} I_{F, t}(j)^{\frac{\varepsilon-1}{\varepsilon}} d j\right]^{\frac{\varepsilon}{\varepsilon-1}} .
$$

The optimal allocation of expenditure in each goods category yields the following demand functions:

$$
I_{H, t}(j)=\left(\frac{P_{H, t}(j)}{P_{H, t}}\right)^{-\varepsilon} I_{H, t} ; \quad I_{F, t}(j)=\left(\frac{P_{F, t}(j)}{P_{F, t}}\right)^{-\varepsilon} I_{F, t} .
$$

The optimal allocation of expenditures between domestic and imported goods gives

$$
I_{H, t}=(1-\gamma)\left(\frac{P_{H, t}}{P_{t}}\right)^{-\eta} I_{t} ; \quad I_{F, t}=\gamma\left(\frac{P_{F, t}}{P_{t}}\right)^{-\eta} I_{t}
$$

From Eqs. (8) and (14), we obtain

$$
P_{H, t} I_{H, t}+P_{F, t} I_{F, t}=P_{t} I_{t}
$$

The capital accumulation process is given as

$$
K_{t+1}=(1-\delta) K_{t}+I_{t}-\frac{\psi^{K}}{2}\left(K_{t+1}-K_{t}\right)^{2}
$$


where $\psi^{K}$ is the capital adjustment cost parameter and $\delta$ is the depreciation rate of physical capital.

The interest rate at which households can borrow in the foreign asset market $i_{t}^{f}$ is given by

$$
i_{t}^{f}=i_{t}^{*}+\psi^{B}\left(\exp \left\{\tilde{B} y_{t}\right\}-1\right)
$$

$i_{t}^{*}$ is the foreign nominal interest rate (henceforth, we use asterisks to denote foreign variables). $\psi^{B}(>0)$ is the parameter for the country-specific interest rate premium. $\tilde{B} y_{t}\left(\equiv \frac{\mathcal{E}_{t}}{P_{t}} \frac{B_{t}}{Y_{t}}-\frac{\mathcal{E}}{P} \frac{B}{Y}\right)$ denotes foreign debt to output ratio's deviation from its steady-state value. This implies that as the foreign debt position deviates from its steady-state level, the cost of foreign borrowing increases.

The optimality conditions associated with households' maximization problem are given by

$$
\begin{gathered}
\left(C_{t}-\chi N_{t}^{\phi}\right)^{-\sigma}=\lambda_{t}, \\
\chi \phi N_{t}^{\phi-1}=\frac{W_{t}}{P_{t}} \\
1=\beta\left(1+i_{t}\right) E_{t}\left\{\frac{\lambda_{t+1}}{\lambda_{t}} \frac{P_{t}}{P_{t+1}}\right\}, \\
1=\beta\left(1+i_{t}^{f}\right) E_{t}\left\{\frac{\lambda_{t+1}}{\lambda_{t}} \frac{P_{t}}{P_{t+1}} \frac{\mathcal{E}_{t+1}}{\mathcal{E}_{t}}\right\},
\end{gathered}
$$

and

$$
1+\psi^{K}\left(K_{t+1}-K_{t}\right)=\beta E_{t}\left\{\frac{\lambda_{t+1}}{\lambda_{t}}\left[1-\delta+\psi^{K}\left(K_{t+2}-K_{t+1}\right)+\frac{R_{t+1}}{P_{t+1}}\right]\right\}
$$


Combining (20) and (21), we obtain the interest parity condition:

$$
\left(1+i_{t}\right) E_{t}\left\{\frac{\lambda_{t+1}}{\lambda_{t}} \frac{P_{t}}{P_{t+1}}\right\}=\left(1+i_{t}^{f}\right) E_{t}\left\{\frac{\lambda_{t+1}}{\lambda_{t}} \frac{P_{t}}{P_{t+1}} \frac{\mathcal{E}_{t+1}}{\mathcal{E}_{t}}\right\}
$$

We assume that the law of one price holds for individual goods. The terms of trade are therefore given as

$$
S_{t} \equiv \frac{P_{F, t}}{P_{H, t}}=\frac{\mathcal{E}_{t} P_{t}^{*}}{P_{H, t}}
$$

where $P_{t}^{*}$ denotes the CPI in the foreign country (in terms of foreign currency). ${ }^{5}$ It follows from Eq. (24) that

$$
\frac{S_{t}}{S_{t-1}}=\frac{\Delta \mathcal{E}_{t}}{\Pi_{H, t}}
$$

where $\Pi_{H, t}\left(\equiv \frac{P_{H, t}}{P_{H, t-1}}\right)$ and $\Delta \mathcal{E}_{t}\left(\equiv \frac{\mathcal{E}_{t}}{\mathcal{E}_{t-1}}\right)$ represent the rate of domestic inflation and the depreciation rate of the nominal exchange rate, respectively. From the CPI (8) and Eq.(24), we have

$$
\frac{P_{t}}{P_{H, t}}=\left[(1-\gamma)+\gamma S_{t}^{1-\eta}\right]^{\frac{1}{1-\eta}} \equiv g\left(S_{t}\right)
$$

It follows from Eq. (26) that

$$
\Pi_{t}=\Pi_{H, t} \frac{g\left(S_{t}\right)}{g\left(S_{t-1}\right)}
$$

where $\Pi_{t}\left(\equiv \frac{P_{t}}{P_{t-1}}\right)$ denotes the rate of CPI inflation. From Eqs. (24) and

\footnotetext{
$t$.

${ }^{5}$ Without loss of generality, we assume that $P_{t}^{*}$ is exogenous and constant $(=1)$ for all
} 
(26), we can express the real exchange rate $Q_{t}$ as the function of $S_{t}$ :

$$
Q_{t} \equiv \frac{\mathcal{E}_{t} P_{t}^{*}}{P_{t}}=\frac{S_{t}}{g\left(S_{t}\right)} \equiv q\left(S_{t}\right)
$$

\section{$2.2 \quad$ Firms}

Each monopolistic firm $j$ in the home economy produces a differentiated good with the following production function:

$$
Y_{t}(j)=Z_{t} K_{t}(j)^{\alpha} N_{t}(j)^{1-\alpha}
$$

where $Y_{t}(j), K_{t}(j), N_{t}(j)$, and $Z_{t}$ denote the firm's output level, its capital and labor inputs, and a stochastic productivity shock, respectively.

From the first-order conditions associated with the firm's cost minimization, we have

$$
(1-\alpha)\left(\frac{R_{t}^{K}}{P_{H, t}}\right) K_{t}(j)=\alpha\left(\frac{W_{t}}{P_{H, t}}\right) N_{t}(j) .
$$

Considering (30), we obtain the firm's real marginal cost:

$$
M C_{t}(j)=M C_{t}=\frac{\left(R_{t} / P_{H, t}\right)^{\alpha}\left(W_{t} / P_{H, t}\right)^{1-\alpha}}{Z_{t} \alpha^{\alpha}(1-\alpha)^{1-\alpha}}
$$

Following Calvo (1983), we assume that in each period, a fraction $1-\zeta$ of firms reset their prices, while a fraction $\zeta$ keep their prices unchanged. This implies that the domestic price index can be expressed as

$$
P_{H, t} \equiv\left[\zeta P_{H, t-1}^{1-\varepsilon}+(1-\zeta) \bar{P}_{H, t}^{1-\varepsilon}\right]^{\frac{1}{1-\varepsilon}}
$$


where $\bar{P}_{H, t}$ represents the price reset in period $t$. Transforming (32) yields

$$
1=\zeta \Pi_{H, t}^{-1+\varepsilon}+(1-\zeta) \tilde{P}_{H, t}^{1-\varepsilon}
$$

where $\tilde{P}_{H, t} \equiv \frac{\bar{P}_{H, t}}{P_{H, t}}$ denotes the relative price of a good, the price of which is adjusted in period $t$ in terms of the composite good.

Each firm chooses its price to maximize the present discounted value of its profit stream:

$$
\max _{\bar{P}_{H, t}} \sum_{k=0}^{\infty} \zeta^{k} E_{t}\left\{\Lambda_{t, t+k}\left[Y_{t+k \mid t}\left(\bar{P}_{H, t}-M C_{t+k \mid t}^{n}\right)\right]\right\}
$$

subject to

$$
Y_{t+k \mid t}=\left(\frac{\bar{P}_{H, t}}{P_{H, t+k}}\right)^{-\varepsilon} Y_{t+k}
$$

where $Y_{t+k \mid t}$ and $M C_{t+k \mid t}^{n}$ denote the output level and the nominal marginal cost, respectively, in $t+k$ for a firm that last reset its price in period $t$. $\Lambda_{t, t+k} \equiv \beta^{k} \frac{\lambda_{t+k}}{\lambda_{t}} \frac{P_{t}}{P_{t+k}}$ is the discount factor. $Y_{t+k}$ is the aggregate output level in period $t+k$. From the first-order condition associated with the above problem, the optimal price is determined as

$$
\tilde{P}_{H, t}=\frac{\varepsilon}{\varepsilon-1} \frac{\sum_{k=0}^{\infty} \zeta^{k} E_{t}\left\{\Lambda_{t, t+k}\left(\frac{P_{H, t}}{P_{H, t+k}}\right)^{-\varepsilon-1} Y_{t+k} M C_{t+k \mid t}\right\}}{\sum_{k=0}^{\infty} \zeta^{k} E_{t}\left\{\Lambda_{t, t+k}\left(\frac{P_{H, t}}{P_{H, t+k}}\right)^{-\varepsilon} Y_{t+k}\right\}}
$$




\subsection{Government}

We assume that the government collects a lump-sum tax to finance government spending. The government's budget constraint is given by

$$
T_{t}=P_{t} G_{t}
$$

where

$$
G_{t} \equiv\left[(1-\gamma)^{\frac{1}{\eta}} G_{H, t}^{\frac{\eta-1}{\eta}}+\gamma^{\frac{1}{\eta}} G_{F, t}^{\frac{\eta-1}{\eta}}\right]^{\frac{\eta}{\eta-1}}
$$

Similar to $C_{t}$ and $I_{t}$, it holds that

$$
G_{H, t}=(1-\gamma)\left(\frac{P_{H, t}}{P_{t}}\right)^{-\eta} G_{t} ; \quad G_{F, t}=\gamma\left(\frac{P_{F, t}}{P_{t}}\right)^{-\eta} G_{t}
$$

From Eqs. (8) and (39), we obtain

$$
P_{H, t} G_{H, t}+P_{F, t} G_{F, t}=P_{t} G_{t} .
$$

Since the government's budget is balanced in each period, there is no public debt in our model. We do not include public debt in our model because our study focuses on examining how monetary policy can be conducted to manage the private sector's capital inflow and outflow and stabilize the boom and bust cycle of emerging market economies. 


\subsection{Equilibrium and exogenous shocks}

Market clearing for domestic goods must satisfy

$$
P_{H, t} Y_{t}=P_{H, t} C_{H, t}+P_{H, t} I_{H, t}+P_{H, t} G_{H, t}+\mathcal{E}_{t} E X_{t}
$$

where the domestic good is also exported to the foreign country, demand for which is assumed to be an exogenous stochastic process, $E X_{t}$. Dividing both sides of (41) by $P_{H, t}$ yields

$$
\begin{aligned}
Y_{t} & =C_{H, t}+I_{H, t}+G_{H, t}+S_{t} E X_{t} \\
& =(1-\gamma) g\left(S_{t}\right)^{\eta}\left(C_{t}+I_{t}+G_{t}\right)+S_{t} E X_{t},
\end{aligned}
$$

where the second equality is derived by considering the demand functions (7), (14), (26), and (39).

Eq. (29) and the homogeneous of degree 1 production function imply that

$$
\int_{0}^{1} Y_{t}(j) d j=Z_{t} K_{t}^{\alpha} N_{t}^{1-\alpha}
$$

where $K_{t}=\int_{0}^{1} K_{t}(j) d j$, and $N_{t}=\int_{0}^{1} N_{t}(j) d j$. From the demand function for differentiated goods, it follows that

$$
\int_{0}^{1}\left(\frac{P_{H, t}(j)}{P_{H, t}}\right)^{-\varepsilon} Y_{t} d j=Z_{t} K_{t}^{\alpha} N_{t}^{1-\alpha}
$$

We define $\theta_{t} \equiv \int_{0}^{1}\left(\frac{P_{H, t}(j)}{P_{H, t}}\right)^{-\varepsilon} d j$, which indicates a measure of price dispersion 
across firms. Here, $\theta_{t}$ can also be expressed as ${ }^{6}$

$$
\theta_{t}=(1-\zeta) \tilde{P}_{H, t}^{-\varepsilon}+\zeta \Pi_{H, t}^{\varepsilon} \theta_{t-1}
$$

Using $\theta_{t}$, we also can rewrite (45) as

$$
Y_{t}=\theta_{t}^{-1} Z_{t} K_{t}^{\alpha} N_{t}^{1-\alpha}
$$

Eq. (47) shows that a larger value of $\theta_{t}$ means the larger resource cost, owing to the price dispersion.

It follows from (9), (15), and (40) that

$$
\left\{P_{H, t} Y_{t}-P_{H, t}\left(C_{H, t}+I_{H, t}+G_{H, t}\right)\right\}-\left\{P_{F, t}\left(C_{F, t}+I_{F, t}+G_{F, t}\right)\right\}=P_{H, t} Y_{t}-P_{t}\left(C_{t}+I_{t}+G_{t}\right) .
$$

Dividing (48) by $P_{H, t}$ and from (26), we define the trade balance as

$$
T B_{t} \equiv Y_{t}-g\left(S_{t}\right)\left(C_{t}+I_{t}+G_{t}\right)
$$

From the budget constraints of both households (10) and the government (37), we define the current account as

$$
C A_{t} \equiv S_{t}\left(-B_{t}+B_{t-1}\right)=T B_{t}-i_{t-1}^{f} S_{t} B_{t-1}
$$

The productivity shock $Z_{t}$, the export shock $E X_{t}$, the foreign (nominal) interest-rate shock $i_{t}^{*}$, and the government spending shock $G_{t}$ are exogenously

\footnotetext{
${ }^{6}$ For the derivation of (46), see Schmitt-Grohé and Uribe (2006).
} 
evolving according to the following processes:

$$
\log Z_{t}=\left(1-\rho_{z}\right) \log Z+\rho_{z} \log Z_{t-1}+\varepsilon_{z, t}, \quad \varepsilon_{z, t} \sim \text { i.i.d. } N\left(0, \sigma_{z}^{2}\right)
$$

$\log E X_{t}=\left(1-\rho_{e x}\right) \log E X+\rho_{e x} \log E X_{t-1}+\varepsilon_{e x, t}, \quad \varepsilon_{e x, t} \sim i . i . d . \quad N\left(0, \sigma_{e x}^{2}\right)$

$$
i_{t}^{*}=\left(1-\rho_{i}\right) i^{*}+\rho_{i} i_{t-1}^{*}+\varepsilon_{i, t}, \quad \varepsilon_{i, t} \sim i . i . d . N\left(0, \sigma_{i}^{2}\right)
$$

and

$$
\log G_{t}=\left(1-\rho_{g}\right) \log G+\rho_{g} \log G_{t-1}+\varepsilon_{g, t} . \quad \varepsilon_{g, t} \sim \text { i.i.d. } N\left(0, \sigma_{g}^{2}\right)
$$

\subsection{Monetary policy rule}

We posit the following simple monetary policy rule:

$$
\tilde{i}_{t}=\Gamma_{\Pi} \tilde{\Pi}_{H, t}+\Gamma_{Y} \tilde{Y}_{t}+\Gamma_{B} \tilde{B} y_{t}
$$

where $\tilde{i}_{t}\left(\equiv i_{t}-i\right), \tilde{\Pi}_{H, t}\left(\equiv \frac{\Pi_{H, t}-\Pi_{H}}{\Pi_{H}}\right)$, and $\tilde{Y}_{t}\left(\equiv \frac{Y_{t}-Y}{Y}\right)$ denote the nominal interest rate, domestic inflation, and output deviations from their steadystate values, respectively. $\Gamma_{\Pi}, \Gamma_{Y}$, and $\Gamma_{B}$ are the parameter values that represent the monetary authority's policy stance. In the case of $\Gamma_{B}=0$, the monetary policy rule can be reduced to a standard Taylor-type interest rate rule. On the other hand, in the case of $\Gamma_{B}>0$, the monetary authority raises the nominal interest rate against a rise of the foreign debt to output ratio. 


\section{Calibration}

This subsection presents calibration of the model parameters and stochastic shocks, which are summarized in Table 1. Following Elekdağ and Tchakarov (2007), we use the U.S. 3-month certificate of deposit (CD) rate from 1990Q1 to $2013 \mathrm{Q} 1$ to calibrate the foreign interest rate shock. ${ }^{7}$ We seasonally adjusted the data using the Census Bureau's X-12-ARIMA program and applied the Hodrick-Prescott filter with a smoothing parameter of 1600 to obtain the following parameter estimates: $\rho_{i}=0.93$ and $\sigma_{i}=0.004$. We also follow Elekdağ and Tchakarov (2007) to calibrate the export shock and use the export volume series for available emerging countries. ${ }^{8}$ We fit Eq. (52) to each country's detrended data. We averaged the estimates to obtain $\rho_{e x}=0.43$ and $\sigma_{e x}=0.056$. To calibrate the government's spending shock for relevant emerging countries, we used government consumption expenditures from the International Financial Statistics database. ${ }^{9}$ We averaged the estimates to determine that $\rho_{g}=0.50$ and $\sigma_{g}=0.043$. It is generally difficult to obtain reliable productivity series for emerging countries owing to the limited availability of data. Following previous studies (e.g., Neumeyer and Perri (2005)), we assumed that the productivity series had the same persistence as the pro-

\footnotetext{
${ }^{7}$ The source for the 3-month certificate of deposit: secondary market rate (CD3M) is the Federal Reserve Bank of St. Louis FRED Database: http://research.stlouisfed.org/fred2/series/CD3M/downloaddata.

${ }^{8}$ Export volume data for Brazil, Korea, Thailand, and Turkey are available from the International Monetary Fund's International Financial Statistics (IFS) database. Data are collected from 1990Q1 to 2012Q4 (except for Brazil, which is collected up to 2013Q1). The raw series were seasonally adjusted, logged, and detrended using the Hodrick-Prescott filter.

${ }^{9}$ Data are collected from 1990Q1 to 2012Q4 (except for Korea and Turkey, for which data are collected up to 2012Q3). We used GDP deflators to determine government consumption expenditure in real terms. The raw series were seasonally adjusted, logged, and filtered using the Hodrick-Prescott filter.
} 
cess estimated for developed countries and accordingly set the productivity shock volatility to render the model close to the data. ${ }^{10}$

Standard values for the other parameters followed those used in the relevant literature. We set the quarterly discount factor $(\beta)$ to 0.99 (e.g., Galí and Monacelli (2005)). The inverse of intertemporal elasticity of substitution $(\sigma)$ was set to 2. Following Neumeyer and Perri (2005), we set the curvature of labor $\phi$ to 1.6 , which implies the elasticity of labor supply given by $\frac{1}{\phi-1}$ is about 1.7. $\chi$ was chosen to generate steady-state labor hours $(h)$ of onethird. The capital share in production $(\alpha)$ was set to 0.32 . Following Galí and Monacelli (2005), we set the elasticity of substitution among differentiated goods $\epsilon$ to 6 . Following Galí and Monacelli (2005), we set the fraction of firms that do not reset their prices $\zeta$ to 0.75. Following Kollmann (2002), we set physical capital's quarterly depreciation rate $\delta$ to 0.025 . Following Ravenna and Natalucci (2008), we set the elasticity of substitution between domestic and foreign goods $(\eta)$ to 1.5. Following Cook (2004), we set the degree of openness $\gamma$ to 0.28 . The capital adjustment cost parameter $\psi^{K}$ and the country-specific interest rate premium parameter $\psi^{B}$ govern investment and the trade balance to output ratio volatilities. We set $\psi^{K}$ and $\psi^{B}$ to match the standard deviation of investment as well as of the trade balance to output ratio with their data as closely as possible $\left(\psi^{K}=9\right.$ and $\left.\psi^{B}=0.08\right)$. Following Aguiar and Gopinath (2007), we set the steady-state level of foreign debt to GDP $\left(\frac{b}{y}\right)$ to 0.1 . In calibrating interest rate rules, we followed Taylor (1993)'s estimates and set $\Gamma_{\Pi}$ and $\Gamma_{Y}$ to 1.5 and 0.5 , respectively.

\footnotetext{
${ }^{10}$ We set $\rho_{z}$ to 0.73 , which fits between Galí and Monacelli (2005)'s estimation of 0.66 for Canada and DeJong and Dave (2011)'s estimation of 0.78 for the United States.
} 
Table 1: Calibration.

\begin{tabular}{lll}
\hline Parameters & Value & \\
\hline$\rho_{i}$ & 0.93 & Persistence: foreign interest rate shock \\
$\sigma_{i}$ & 0.004 & Standard deviation: foreign interest rate shock \\
$\rho_{e x}$ & 0.43 & Persistence: export shock \\
$\sigma_{e x}$ & 0.056 & Standard deviation: export shock \\
$\rho_{g}$ & 0.50 & Persistence: government spending shock \\
$\sigma_{g}$ & 0.043 & Standard deviation: government spending shock \\
$\rho_{z}$ & 0.73 & Persistence: productivity shock \\
$\sigma_{z}$ & 0.045 & Standard deviation: productivity shock \\
$\beta$ & 0.99 & Discount factor \\
$\sigma$ & 2 & Inverse of intertemporal elasticity of substitution \\
$\phi$ & 1.6 & Curvature parameter in labor \\
$\chi$ & 1.8 & Labor coefficient \\
$h$ & 0.33 & Steady-state value of labor \\
$\alpha$ & 0.32 & Share of capital in output \\
$\epsilon$ & 6 & Elasticity of substitution among differentiated goods \\
$\zeta$ & 0.75 & Fraction of firms that do not reset their prices \\
$\delta$ & 0.025 & Depreciation rate of capital \\
$\eta$ & 1.5 & Elasticity of substitution between domestic and foreign goods \\
$\gamma$ & 0.28 & Degree of openness \\
$\psi^{K}$ & 9 & Capital adjustment cost parameter \\
$\psi^{B}$ & 0.08 & Parameter for country-specific interest rate premium \\
$\frac{b}{y}$ & 0.1 & Steady state level of foreign debt to GDP \\
$\Gamma_{\Pi}$ & 1.5 & Domestic inflation coefficient of interest rate rules \\
$\Gamma_{Y}$ & 0.5 & Output coefficient of interest rate rules \\
\hline & &
\end{tabular}


Following Elekdağ and Tchakarov (2007), we chose Argentina, Brazil, Indonesia, Korea, Malaysia, the Philippines, Thailand, and Turkey as our subject emerging market economies and reported their key business cycle statistics. $^{11}{ }^{12}$ The model competently replicates key variable dynamics. Although it predicts slightly lower volatility of $T B / Y$ ratio than the data average, all simulated moments range between the sample countries' minimum and maximum values, and most simulated moments are close to the data moments averages.

\footnotetext{
${ }^{11}$ The raw series were seasonally adjusted and transformed to both real and per capita terms. We took logs (except for the $T B / Y$ ratio) and applied the Hodrick-Prescott filter with a smoothing parameter of 1600 .

${ }^{12}$ Neumeyer and Perri (2005) and Unsal (2013) chose Argentina, Brazil, Korea, Mexico, and the Philippines as emerging economies. Similarly, as in Unsal (2013), we compare the simulated moments with the data, including the average values.
} 
Table 2: Business cycles in emerging economies: Data vs. model

\begin{tabular}{|c|c|c|c|c|}
\hline \multicolumn{5}{|c|}{ Standard deviations (in \%) } \\
\hline & Output & Consumption & Investment & $\mathrm{TB} / \mathrm{Y}$ ratio \\
\hline Argentina & 4.70 & 5.80 & 12.51 & 2.53 \\
\hline Brazil & 1.94 & 2.16 & 4.88 & 0.83 \\
\hline Indonesia & 2.88 & 4.32 & 6.93 & 2.23 \\
\hline Korea & 2.52 & 4.06 & 5.37 & 2.76 \\
\hline Malaysia & 2.65 & 4.11 & 11.43 & 4.20 \\
\hline Philippines & 1.41 & 1.12 & 5.57 & 2.56 \\
\hline Thailand & 3.68 & 3.47 & 11.91 & 4.09 \\
\hline Turkey & 3.82 & 4.32 & 11.40 & 2.43 \\
\hline average & 2.95 & 3.67 & 8.75 & 2.71 \\
\hline model & 3.25 & 3.99 & 8.12 & 2.04 \\
\hline \multicolumn{5}{|c|}{ Standard deviations relative to output } \\
\hline Argentina & 0.82 & 1.23 & 2.66 & 0.54 \\
\hline Brazil & 0.33 & 1.12 & 2.52 & 0.43 \\
\hline Indonesia & 0.79 & 1.50 & 2.41 & 0.78 \\
\hline Korea & 0.79 & 1.61 & 2.13 & 1.09 \\
\hline Malaysia & 0.81 & 1.55 & 4.31 & 1.59 \\
\hline Philippines & 0.78 & 0.80 & 3.96 & 1.82 \\
\hline Thailand & 0.74 & 0.94 & 3.24 & 1.11 \\
\hline Turkey & 0.72 & 1.13 & 2.99 & 0.64 \\
\hline average & 0.72 & 1.24 & 3.03 & 1.00 \\
\hline model & 0.77 & 1.23 & 2.50 & 0.63 \\
\hline
\end{tabular}

Note) The samples are as follows: Argentina, 1993Q1-2012Q4; Brazil, 1995Q1-2011Q4; Indonesia, 1997Q1-2012Q4; Korea, 1990Q1-2012Q3; Malaysia, 1991Q1-2012Q4; The Philippines, 1990Q1-2012Q4; Thailand, 1993Q1-2012Q4; Turkey, 1990Q1-2012Q3. Source: IFS. 


\section{Welfare}

We perform a comparative welfare analysis in two cases featuring different interest rate rules. Both cases use the standard Taylor-type interest rate rules, but the second case also considers external debt levels.

We use the perturbation methods presented by Schmitt-Grohé and Uribe (2004) for computing second-order accurate solutions to measure lifetime utility levels. ${ }^{13}$ We conduct policy evaluations by comparing measured welfare levels under different values of $\Gamma_{B}$ to the welfare level under standard Taylor-type interest rate rules (i.e., $\Gamma_{B}=0$ ).

We define lifetime utility in the case of the standard Taylor-type interest rate rules (i.e., $\Gamma_{B}=0$ ) as the benchmark case (i.e., "policy regime $b$ "):

$$
V_{0}^{b} \equiv E_{0} \sum_{t=0}^{\infty} \beta^{t} U\left(C_{t}^{b}, N_{t}^{b}\right)
$$

We next define lifetime utility having different $\Gamma_{B}$ values as alternative policy regimes (i.e., "policy regime $a$ "):

$$
V_{0}^{a} \equiv E_{0} \sum_{t=0}^{\infty} \beta^{t} U\left(C_{t}^{a}, N_{t}^{a}\right)
$$

Then, we define $\kappa$ as the welfare benefit of adopting policy regime $a$ rather than adopting policy regime $b$. Formally, $\kappa$ can be defined as

$$
V_{0}^{a}=E_{0} \sum_{t=0}^{\infty} \beta^{t} U\left((1+\kappa) C_{t}^{b}, N_{t}^{b}\right)
$$

\footnotetext{
${ }^{13} \mathrm{Kim}$ and Kim (2003) show that second-order solutions are necessary because conventional linearization can generate spurious welfare reversals.
} 
In other words, $\kappa$ is the fraction of regime $b$ 's consumption process that compensates a household to a level considered as well off under regime $b$ as under regime $a .^{14}$

The solid curve in Figure 1 depicts the welfare benefits $(\kappa)$ of adopting different $\Gamma_{B}$ values instead of the benchmark case of $\Gamma_{B}=0$. In Figure 1, the economy's welfare curve forms a hump shape. Clearly, some range of $\Gamma_{B}\left(0<\Gamma_{B}<0.47\right)$ improves welfare levels compared to the benchmark case of $\Gamma_{B}=0$. The optimal value of $\Gamma_{B}, 0.22$, achieves the maximum value of the welfare benefit of $3.9 \%$. To provide the rationale behind our results, we present the standard deviations of debt to output ratio $B y_{t}$, output $Y_{t}$, and interest rate $i_{t}$ that correspond to different $\Gamma_{B}$ values in Figure 2. Figure 2 (a) shows that higher $\Gamma_{B}$ decreases the volatility of debt to output ratio $B y_{t}$. Eq. (55) shows that a higher $\Gamma_{B}$ indicates that the monetary authority will react to a change in debt more strongly, leading to reduced volatility in $B y_{t}$. Decreased debt volatility lowers volatility of the country-specific interest rate premium in Eq. (17). This implies that, starting from 0, a higher $\Gamma_{B}$ value leads to reduced volatility of interest rate $i_{t}$ as shown in Figure 2 (c). However, a higher $\Gamma_{B}$ in Eq. (55) implies a lower relative weight of output deviations compared with that of debt deviations in monetary policy. As shown in Figure $2(\mathrm{~b})$, therefore, the higher $\Gamma_{B}$ results in higher output $Y_{t}$ volatility. Since output volatility increases monotonically (as $\Gamma_{B}$ increases), we can determine from Eq. (55) that interest rate volatility finally begins

\footnotetext{
${ }^{14}$ Specifically, we obtained $\kappa$ as follows. We first measured the percentage change from the deterministic steady-state consumption level that would in each case give households the same expected utility in the stochastic economy. Using the measured percentage change in each case, we calculated the welfare benefits of adopting different $\Gamma_{B}$ values instead of the benchmark case of $\Gamma_{B}=0$.
} 
increasing. Due to the trade-off between debt and output volatility, we have a U-shaped curve in the interest rate volatility (in Figure 2 (c)), which implies the hump-shaped welfare curve seen in Figure 1. We can also confirm that the volatility of domestic inflation $\Pi_{H}$ has the U-shaped curve as shown in Figure $2(\mathrm{~d})$, consistent with the hump-shaped welfare curve in Figure 1.

Figure 3 plots the impulse responses of $B_{y}, Y, i$, and $\Pi_{H}$ to one standard deviation of the productivity shock $\varepsilon_{z}$. In Figure 3, the solid line, "-," indicates the impulse response of each variable in the benchmark case of $\Gamma_{B}=0$, while the dashed line, "- - -," indicates the impulse response of each variable in the optimal case of $\Gamma_{B}=0.22$. From Figure 3 (a), we find that the optimal value of $\Gamma_{B}$ leads to reduced volatility of $B_{y}$ (i.e., the dashed line of the optimal case, "- - -," is closer to zero than the solid line of the benchmark case, "-"). However, Figure 3 (b) indicates that the optimal value of $\Gamma_{B}$ leads to increased volatility of $Y$ (i.e., the dashed line of the optimal case, "- -," is farther from zero than the solid line of the benchmark case, "_" ). This contrast between $B_{y}$ and $Y$ is consistent with the trade-off between debt and output volatility shown in Figure 2. A higher $\Gamma_{B}$ results in a higher volatility of $Y$ (as shown in Figure $2(\mathrm{~b})$ ), but results in a lower volatility of $B_{y}$ (as shown in Figure $2(\mathrm{a}))$. With regard to the interest rate $i$ and domestic inflation $\Pi_{H}$, Figures $3(\mathrm{c})$ and $(\mathrm{d})$ indicate that the optimal value of $\Gamma_{B}$ leads to reduced volatility of $i$ and $\Pi_{H}$, respectively (i.e., the dashed line of the optimal case, "- - -," is closer to zero than the solid line of the benchmark case, "-"). These results on $i$ and $\Pi_{H}$ are consistent with the finding that we have a $\mathrm{U}$-shaped curve in the volatility of interest rate $i$ (Figure 2 (c)) and that of domestic inflation $\Pi_{H}$ (Figure $\left.2(\mathrm{~d})\right)$. 
To clarify the results of our analysis, we compare the economy's welfare benefit curve in this case with those cases in which the country-specific interest rate premium parameter $\psi_{B}$ is set to higher values. The dash-dotted curve (-.) and dashed curve (--) in Figure 1 depict the welfare benefits corresponding to the various values of $\Gamma_{B}$ for the cases in which $\psi_{B}$ increases by half and double the calibrated value (i.e., 0.12 and 0.16 , respectively). A comparison of these three cases (i.e., the solid, dash-dotted, and dashed curves) shows that as the country-specific interest rate premium increases, the maximum welfare benefit achieved by the optimal value of $\Gamma_{B}$ increases. This implies that the positive effect from adding the external debt level to the standard Taylor rule becomes increasingly important, as the friction in foreign borrowing becomes greater. 


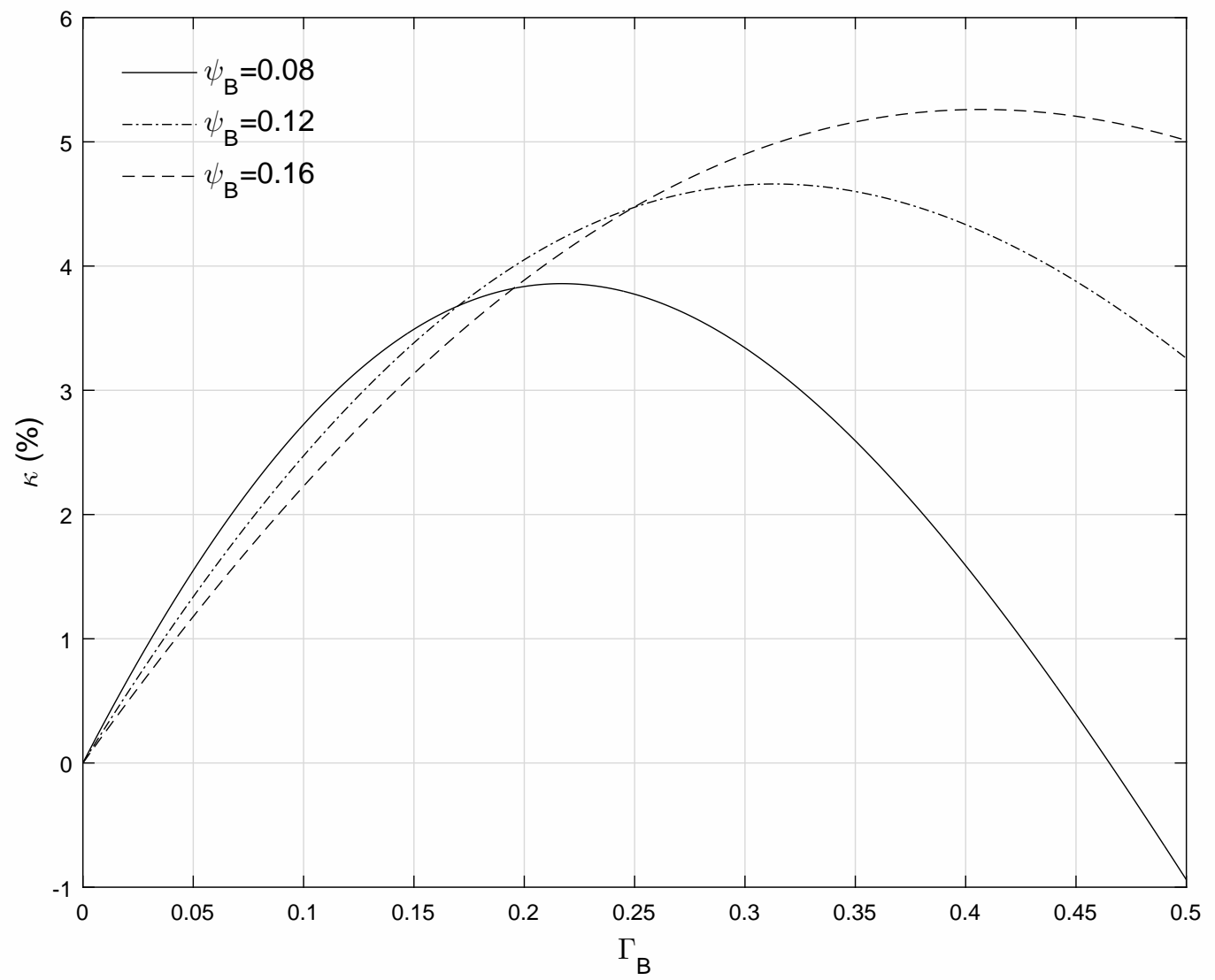

Figure 1: Welfare 
(a)

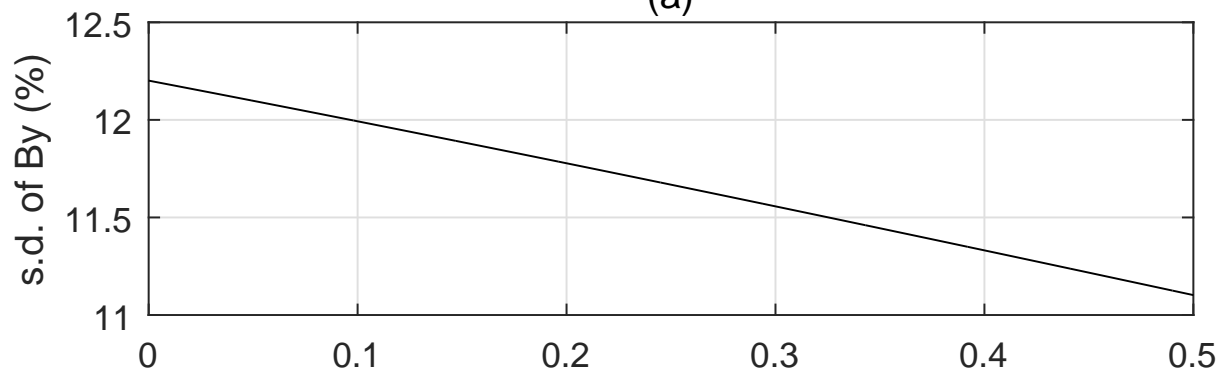

(b)

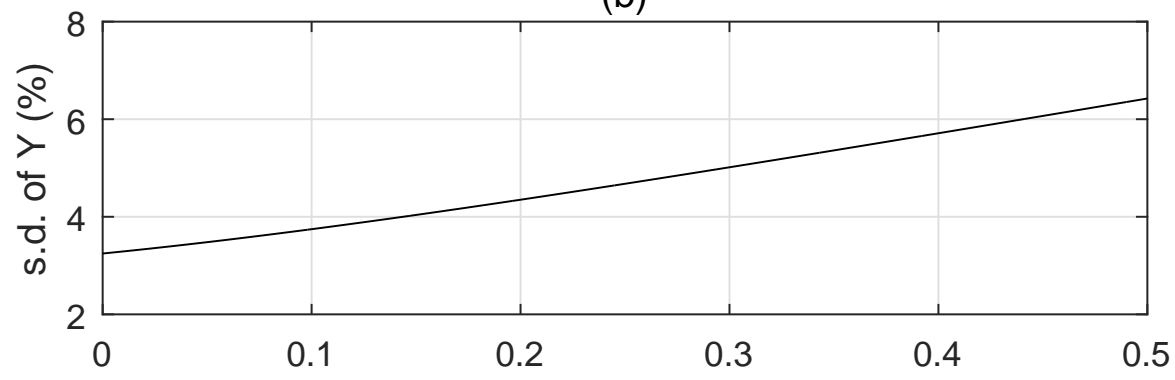

(c)

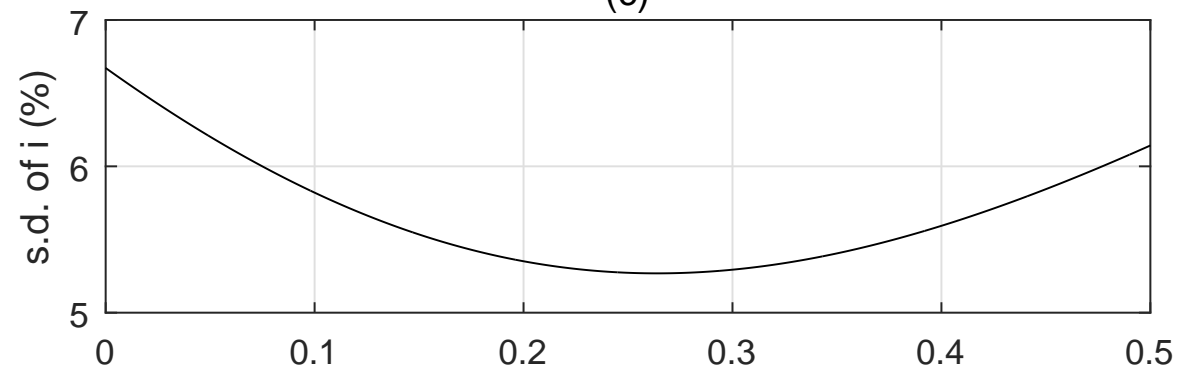

(d)

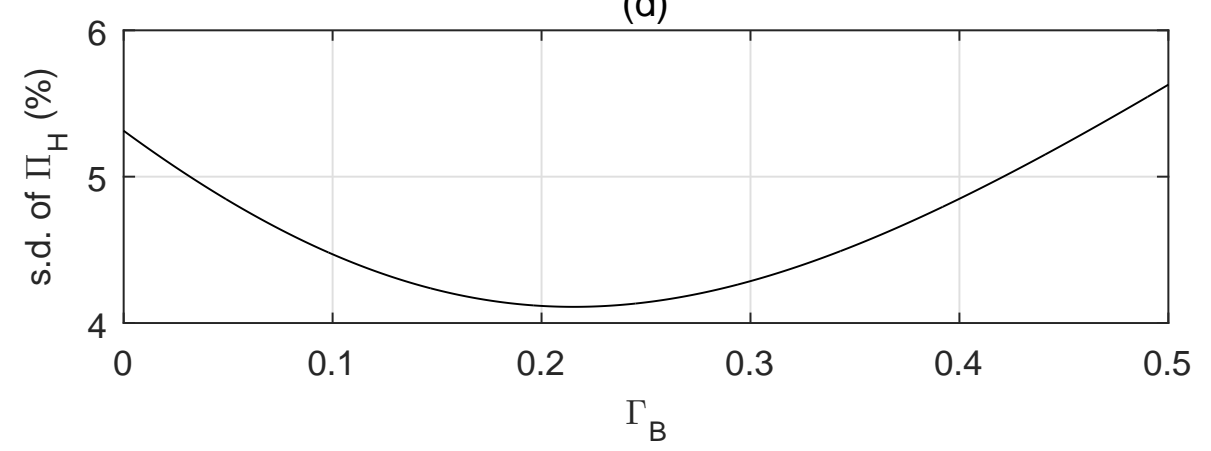

Figure 2: Standard deviations of debt to output ratio, output, interest rate, and domestic inflation 
(a) $B_{Y}$

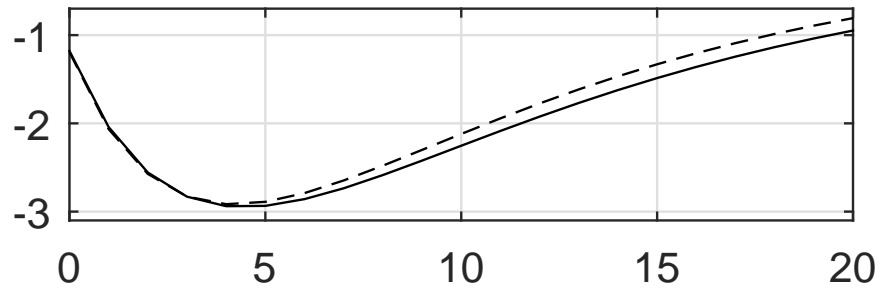

(b) $Y$

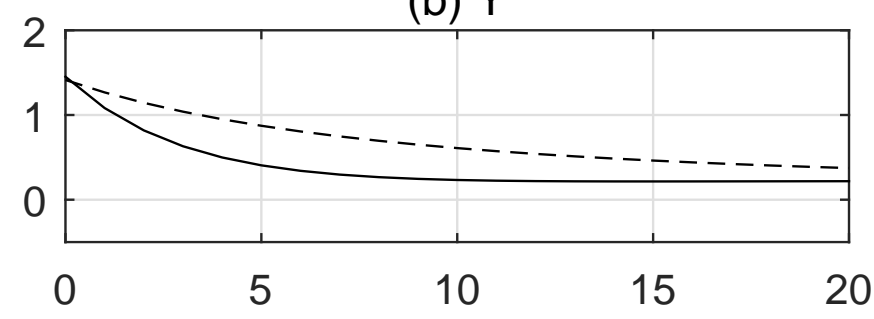

(c) $\mathrm{i}$

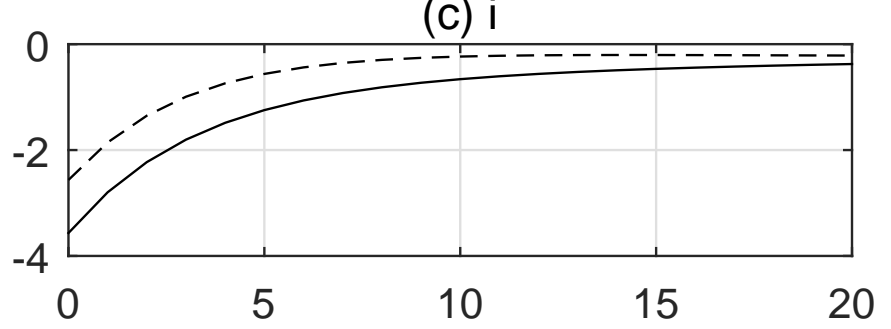

(d) $\Pi_{H}$

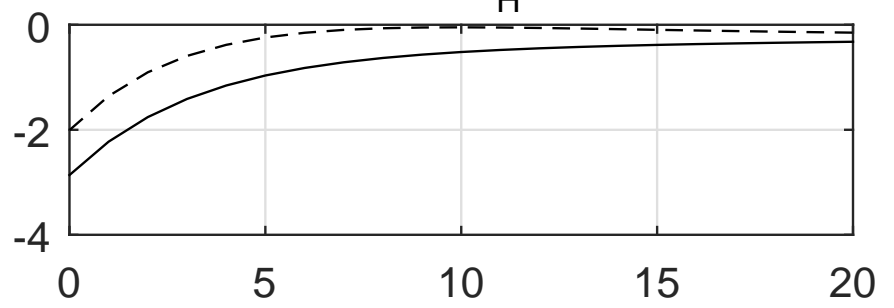

Figure 3: Impulse responses (in percent) 


\section{Conclusion}

In this paper, we developed a standard DSGE model of a small open economy calibrated specifically to emerging market economies incorporating both price rigidity and a reduced form of financial friction à la Garcia-Cicco et al. (2010). Comparing a case featuring the standard Taylor-type interest rate rule with one using an augmented rule with an external debt level, we found that when the debt elasticity of the country premium is large, adding an external debt level to the Taylor rule can improve welfare. Country premiums of emerging market economies are significantly higher than those of developed countries, and they tend to rise as the countries accumulate external debt. Our result implies that, given the greater friction in foreign borrowing, policy makers in emerging market economies should consider external debt levels when making monetary policy decisions.

In this study, following Garcia-Cicco et al. (2010) and Aguiar and Gopinath (2007), we adopt the simple setting that the country's risk premium increases as the private foreign-debt level increases (and vice versa). This is because our study focuses on private capital flows and related policies in emerging economies. However, as Corsetti et al. (2013) argue, other factors, such as sovereign risk, can also affect a country's risk premium, in addition to its external debt position. A more general argument related to a country's risk premium might be important. We leave this as a subject for future research. 


\section{References}

Aguiar, Mark and Gita Gopinath (2007) "Emerging Market Business Cycles: The Cycle Is the Trend," Journal of Political Economy, Vol. 115, pp. 69102.

Ball, Laurence M. (1999) "Policy Rules for Open Economies," in Taylor, John B. ed. Monetary Policy Rules: National Bureau of Economic Research, Inc, pp. 127-156.

Bernanke, Ben and Mark Gertler (1999) "Monetary policy and asset price volatility," Economic Review, No. Q IV, pp. 17-51.

Bernanke, Ben S., Mark Gertler, and Simon Gilchrist (1999) "The financial accelerator in a quantitative business cycle framework," in Taylor, J. B. and M. Woodford eds. Handbook of Macroeconomics, Vol. 1 of Handbook of Macroeconomics: Elsevier, Chap. 21, pp. 1341-1393.

Calvo, Guillermo A. (1983) "Staggered prices in a utility-maximizing framework," Journal of Monetary Economics, Vol. 12, No. 3, pp. 383 - 398.

Cecchetti, Stephen G., Hans Genberg, John Lipsky, and Sushil Wadhwani (2000) Asset Prices and Central Bank Policy, Geneva reports on the world economy: International Center for Monetary and Banking Studies.

Christiano, Lawrence, Roberto Motto, and Massimo Rostagno (2007) "Two Reasons Why Money and Credit May be Useful in Monetary Policy," Working Paper 13502, National Bureau of Economic Research. 
Christiano, Lawrence, Cosmin Ilut, Roberto Motto, and Massimo Rostagno (2008) "Monetary policy and stock market boom-bust cycles," Working Paper Series 0955, European Central Bank.

Clarida, Richard, Jordi Gali, and Mark Gertler (1998) "Monetary policy rules in practice Some international evidence," European Economic Review, Vol. 42, No. 6, pp. 1033-1067.

Cook, David (2004) "Monetary policy in emerging markets: Can liability dollarization explain contractionary devaluations?" Journal of Monetary Economics, Vol. 51, No. 6, pp. 1155 - 1181.

Corsetti, Giancarlo, Keith Kuester, André Meier, and Gernot J. Müller (2013) "Sovereign Risk, Fiscal Policy, and Macroeconomic Stability," The Economic Journal, Vol. 123, No. 566, pp. F99-F132.

Cúrdia, Vasco and Michael Woodford (2010) "Credit Spreads and Monetary Policy," Journal of Money, Credit and Banking, Vol. 42, pp. 3-35.

DeJong, David N. and Chetan Dave (2011) Structural Macroeconometrics: Second Edition: Princeton University Press.

Elekdağ, Selim and Ivan Tchakarov (2007) "Balance sheets, exchange rate policy, and welfare," Journal of Economic Dynamics and Control, Vol. 31, No. 12, pp. 3986 - 4015.

Faia, Ester and Tommaso Monacelli (2008) "Optimal Monetary Policy in a Small Open Economy with Home Bias," Journal of Money, Credit and Banking, Vol. 40, No. 4, pp. 721-750. 
Galí, Jordi and Tommaso Monacelli (2005) "Monetary Policy and Exchange Rate Volatility in a Small Open Economy," The Review of Economic Studies, Vol. 72, No. 3, pp. 707-734.

Garcia-Cicco, Javier, Roberto Pancrazi, and Martin Uribe (2010) "Real Business Cycles in Emerging Countries?" American Economic Review, Vol. 100, No. 5, pp. 2510-2531, December.

Gray, Dale F., Carlos J. García, Leonardo Luna, and Jorge Restrepo (2011) "Incorporating Financial Sector Risk into Monetary Policy Models: Application to Chile," IMF Working Papers 11/228, International Monetary Fund.

Jeanne, Olivier, Arvind Subramanian, and John Williamson (2012) Who Needs to Open the Capital Account?: Peterson Institute for International Economics.

Jeanne, Olivier and Anton Korinek (2010) "Excessive Volatility in Capital Flows: A Pigouvian Taxation Approach," American Economic Review, Vol. 100, No. 2, pp. 403-407.

Kannan, Prakash, Pau Rabanal, and Alasdair M. Scott (2012) "Monetary and macroprudential policy rules in a model with house price booms," The B.E. journal of macroeconomics, Vol. 12, Issue 1, Article 16, pp. 1-42.

Kim, Jinill and Sunghyun Henry Kim (2003) "Spurious welfare reversals in international business cycle models," Journal of International Economics, Vol. 60, No. 2, pp. 471-500, August. 
Kitano, Shigeto (2011) "Capital Controls and Welfare," Journal of Macroeconomics, Vol. 33, No. 4, pp. 700-710.

Kollmann, Robert (2002) "Monetary policy rules in the open economy: effects on welfare and business cycles," Journal of Monetary Economics, Vol. 49, No. 5, pp. 989-1015.

Korinek, Anton (2011) "The New Economics of Prudential Capital Controls: A Research Agenda," IMF Economic Review, Vol. 59, No. 3, pp. 523-561.

Neumeyer, Pablo A. and Fabrizio Perri (2005) "Business cycles in emerging economies: the role of interest rates," Journal of Monetary Economics, Vol. 52, No. 2, pp. 345-380, March.

Ravenna, Federico and Fabio M. Natalucci (2008) "Monetary Policy Choices in Emerging Market Economies: The Case of High Productivity Growth," Journal of Money, Credit and Banking, Vol. 40, No. 2-3, pp. 243-271.

Schmitt-Grohé, Stephanie and Martín Uribe (2004) "Solving dynamic general equilibrium models using a second-order approximation to the policy function," Journal of Economic Dynamics and Control, Vol. 28, No. 4, pp. $755-775$.

Schmitt-Grohé, Stephanie and Martin Uribe (2006) "Optimal Simple and Implementable Monetary and Fiscal Rules: Expanded Version," Working Paper 12402, National Bureau of Economic Research.

Senay, Ozge (2008) "Interest Rate Rules And Welfare In Open Economies," Scottish Journal of Political Economy, Vol. 55, No. 3, pp. 300-329. 
Svensson, Lars E. O. (2000) "Open-economy inflation targeting," Journal of International Economics, Vol. 50, No. 1, pp. 155-183, February.

Taylor, John B. (1993) "Discretion versus policy rules in practice," CarnegieRochester Conference Series on Public Policy, Vol. 39, No. 1, pp. 195-214. (2001) "The Role of the Exchange Rate in Monetary-Policy Rules," American Economic Review, Vol. 91, No. 2, pp. 263-267, September.

Unsal, D. Filiz (2013) "Capital Flows and Financial Stability: Monetary Policy and Macroprudential Responses," International Journal of Central Banking, Vol. 9, No. 1, pp. 233-285, March. 